\title{
Circulating concentrations of insulin like growth factor- 1 in female dogs with spontaneous mammary tumours
}

\author{
MAREK SZCZUBIAŁ, ROMAN DAZBROWSKI, WOJCIECH ŁOPUSZYŃSKI*, \\ MARIOLA BOCHNIARZ, MAGDALENA KRAWCZYK, RENATA URBAN-CHMIEL**
}

\begin{abstract}
Department and Clinic of Animal Reproduction, *Department of Pathological Anatomy, Faculty of Veterinary Medicine, University of Life Sciences in Lublin, Głęboka 30, 20-612 Lublin, Poland **Sub-department of Veterinary Prevention and Avian Diseases, Institute of Biological Bases of Animal Diseases, Faculty of Veterinary Medicine, University of Life Sciences in Lublin, Akademicka 12, 20-033 Lublin, Poland
\end{abstract}

\section{Szczubiał M., Dąbrowski R., Łopuszyński W., Bochniarz M., Krawczyk M., Urban-Chmiel R. Circulating concentrations of insulin like growth factor- 1 in female dogs with spontaneous mammary tumours}

\section{Summary}

The aim of this study was the investigation of the circulating concentration of IGF-1 in female dogs with spontaneous mammary tumours. The study was performed on $\mathbf{3 4}$ female dogs undergoing surgery due to spontaneously occurring mammary gland tumours (24 malignant and 10 benign) and 10 clinically healthy female dogs. The serum concentrations of IGF-1 were determined by specific ELISA Kit assay. The mean concentrations of IGF-1 were significantly higher $(P<0.05)$ both in dogs with malignant $(173.35 \pm 120.45 \mathrm{ng} / \mathrm{ml})$ and benign $(130.58 \pm 59.0 \mathrm{ng} / \mathrm{ml})$ mammary tumours than in healthy controls $(117.45 \pm 71.0 \mathrm{ng} / \mathrm{ml})$. In the group of female dogs with mammary carcinomas, the mean concentration of IGF-1 gradually increased from $132.85 \pm 65.64 \mathrm{ng} / \mathrm{ml}$ in dogs with grade 1 tumours to $317.74 \pm 119.25 \mathrm{ng} / \mathrm{ml}$ in those with grade 3 tumours, and significant differences $(\mathrm{P}<\mathbf{0 . 0 5})$ were found among dogs with various grade tumours. These findings suggest that circulating IGF-1 may play an important role in the pathogenesis of canine mammary tumour. Moreover, high IGF-1 levels may reflect tumour cell differentiation into a more aggressive phenotype.

Keywords: IGF-1, mammary tumours, female dogs, serum

Insulin like growth factor-1 (IGF-1) is a polypeptide hormone that is synthetized in a number of tissues, but predominantly in the liver under the influence of growth hormone (GH). IGF-1 mediates many of the anabolic effects of GH in different tissues such as bones, muscle, kidney, spleen, heart or mammary gland (22).

It is well known that GH/IGF-1 axis plays a fundamental role in the development of the human breast (22) and canine mammary gland (14), but is also involved in various neoplastic processes $(17,24)$ including breast cancer $(1,10)$. IGF-1 is a potent mitogenic and anti-apoptotic agent (30), which is also involved in angiogenesis stimulation $(2,20)$. Moreover, some studies suggest IGF-1 has a role in cell-cell adhesion and cell migration (28). It is thought that these features can promote the development and progression of neoplasms $(1,10)$. In humans the role of IGF-1 in tumorigenesis has been investigated intensively. Some of these studies have demonstrated that an elevated serum IGF-1 concentration was associated with an increased risk of breast cancer and other cancers in humans (9). Several authors have reported increased serum IGF-1 concentrations in breast cancer patients compared with healthy control $(2,15)$. The positive correlation has been found between a high serum level of IGF-1 and advanced stage of breast cancer (2). Numerous in vitro and in vivo studies have shown that inhibition of IGF-1 signalling decreases tumour growth and metastasis (8).

In the last years serum IGF-1 levels have also been studied in various aspects in dogs $(3,18,29)$. The implication of the GH/IGF-1 axis in canine mammary tumours has been recently demonstrated $(7,18,19)$. However, studies concerning the serum IGF-1 levels in dogs with mammary tumours are scarce (19).

Canine mammary tumours are the most common neoplasms in intact female dogs and approximately half of these tumours are malignant (26). It is accepted that canine mammary tumours share many epidemiologic, 
clinical, morphologic and prognostic features with human breast cancer and therefore represent a comparative model to understand the underlying molecular mechanisms of carcinogenesis in both species (16). Although many studies have indicated the role of IGF-1 in the pathogenesis and progression of breast cancer, only a few studies have been concerned with this subject in female dogs with mammary tumours.

The aim of this study was the investigation of the circulating concentration of IGF-1 in female dogs with spontaneous mammary tumours.

\section{Material and methods}

Animals and design of study. The study was performed in accordance with animal protection regulations (Animal Experimentation Act dated 15 January 2015).

The study was performed on 44 female dogs of various breeds and mixed-breed, patients of the Department of Animal Reproduction, Faculty of Veterinary Medicine in Lublin. The experimental group consisted of 34 bitches aged 6-10 years, weighting 15 to $23 \mathrm{~kg}$, selected from the group of female dogs undergoing surgery due to spontaneously occurring mammary gland tumours. The control group included 10 clinically healthy female dogs aged $4-8$ years, weighting 14 to $21 \mathrm{~kg}$, undergoing sterilization at the owner's request. The animals had a body condition score (BCS) of 3 in all cases. The BCS was evaluated in accordance with a 5-point scale (11). All female dogs with mammary tumours qualified for the study were diagnosed with a primary, single, tumour, $3.5 \mathrm{~cm}$ to $8.5 \mathrm{~cm}$ in size, without signs of metastases in regional lymph nodes. All animals received a similar diet, consisting of commercial dog food for adult animals and water was given ad libitum. Only female dogs in anoestrus, confirmed by history data and vaginal cytology, were included to the study. No drug, including progestins, was administered during last six months before study.

Before surgery, all animals were thoroughly clinically examined, and routine haematological and biochemical blood determinations, as well as, urine determinations, were performed. Moreover, in the experimented group, three-view thoracic radiographs and abdominal ultrasound examinations were performed. In the experimental animals, there were no other diseases detected except for tumours in mammary glands. Thoracic radiographs and ultrasound examinations excluded distant metastases. The animals of the control group were clinically healthy.

The surgical resection of mammary tumours was performed according to standard practice, with the aim of removing the tumour with complete margins. The sections of removed mammary tumours were fixed in $10 \%$ neutral buffered formalin for $24 \mathrm{~h}$, embedded in paraffin blocks and sliced into $4 \mu \mathrm{m}$ sections. The microscopic preparations, stained with haematoxylin and eosin, were evaluated histologically according to the WHO classification of tumours and mammary gland dysplasia (12). Malignant epithelial neoplasms were graded according to the Nottingham method for human breast tumours, adapted for canine mammary tumours (4). Tubule formation, nuclear pleomorphism and mitotic index were scored on a scale of 1-3 (slight, moderate or marked degree) and grades were based on the total score: grade 1 (well differentiated) - 3-5 points; grade 2 (moderately dif- ferentiated) - 6-7 points; and grade 3 (poorly differentiated) $-8-9$ points.

Based on the histological findings, female dogs were divided into two experimental groups: dogs with malignant mammary tumours $(n=24)$ and dogs with benign mammary tumours $(\mathrm{n}=10)$. Nine millilitres of blood from all female dogs were collected from the cephalic vein into Vacuette tubes immediately before surgery. The serum obtained after centrifugation was immediately frozen to $-76^{\circ} \mathrm{C}$ and kept deeply frozen until used for the determination of IGF-1.

Laboratory analysis. The concentration of IGF-1 in the serum samples was analyzed using a specific canine ELISA assay (Cloud-Clone Corp., Houston, USA) according to the manufacturer's instruction. The detection range was 6.25 $-400 \mathrm{ng} / \mathrm{mL}$. The intra-assay coefficient of variation was $<10 \%$ and the inter-assay coefficient of variation was $<12 \%$.

Statistical analysis. Statistical analysis was performed using the computer program Statistica version 10.0 (Statsoft, USA). The one-way ANOVA test with the HSD Tukey's test were used to determine significant differences in the concentrations of IGF-1 between the study groups. The correlations between IGF-1 concentrations and histological grade of mammary carcinomas were presented using Pearson's correlation coefficient. Differences at $P<0.05$ were considered statistically significant.

\section{Results and discussion}

Among 34 mammary gland tumours, 10 were benign (6 complex adenomas and 4 benign mixed tumours) and 24 malignant (2 in situ carcinoma, 9 complex carcinomas, 8 tubulopapillary carcinomas, 2 anaplastic carcinomas, 2 solid carcinomas, 1 osteosarcoma).

The mean serum concentration of IGF-1 was significantly higher $(P<0.05)$ in female dogs with both benign and malignant tumours compared to the control group. Although the concentration of IGF-1 was markedly higher in dogs with malignant tumours than in dogs with benign tumours a significant difference was not found (Tab. 1).

Tab. 1. Mean \pm SD concentration of IGF-1 in blood plasma of the female dogs with malignant and benign mammary tumours

\begin{tabular}{|l|c|c|}
\hline \multicolumn{1}{|c|}{ Groups } & $\begin{array}{c}\text { Number of } \\
\text { animals }\end{array}$ & $\begin{array}{c}\text { IGF-1 concentration } \\
(\mathrm{ng} / \mathrm{ml})\end{array}$ \\
\hline Dogs with malignant tumour & 24 & $173.35 \pm 120.45^{\mathrm{a}}$ \\
\hline Dogs with benign tumour & 10 & $130.58 \pm 59.0^{\mathrm{a}}$ \\
\hline Control & 10 & $117.45 \pm 71.0^{\mathrm{b}}$ \\
\hline
\end{tabular}

Explanations: ${ }^{\mathrm{a}, \mathrm{b}}$ - different superscripts indicate statistically significant differences at $\mathrm{P}<0.05$

Tab. 2. Mean \pm SD concentration of IGF-1 in blood plasma of the female dogs with various histological grades of malignant epithelial mammary tumours

\begin{tabular}{|c|c|c|}
\hline Histological grade & Number of animals & IGF-1 concentration $(\mathrm{ng} / \mathrm{ml})$ \\
\hline G1 & 8 & $132.85 \pm 65.64^{\mathrm{a}}$ \\
G2 & 10 & $156.21 \pm 120.0^{\mathrm{b}}$ \\
G3 & 5 & $317.74 \pm 119.25^{\mathrm{c}}$ \\
\hline
\end{tabular}

Explanations: ${ }^{\mathrm{a}, \mathrm{b}, \mathrm{c}}-$ different superscripts indicate statistically significant differences at $\mathrm{P}<0.05$ 
In female dogs with mammary carcinomas, the concentration of IGF-1 gradually increased from $132.85 \pm 65.64 \mathrm{ng} / \mathrm{mL}$ in dogs with grade 1 tumours to $317.74 \pm 119.25 \mathrm{ng} / \mathrm{mL}$ in those with grade 3 tumours. Significant differences $(P<0.05)$ were found among female dogs with various histological grade tumours (Tab. 2).

The correlation analysis showed a strong correlation $(r=0.50)$ between serum IGF-1 concentration and histological grade of tumours (Fig. 1).

Studies on IGF-1 levels in the serum of female dogs with mammary tumours are very limited. Our findings are consistent with the previous study by Queiroga et al. (19). These authors have also found significantly higher serum IGF-1 concentrations in female dogs with malignant mammary tumours than in healthy controls; however, malignant mammary tumours cannot be distinguished from benign mammary lesions by serum IGF-1 concentra-

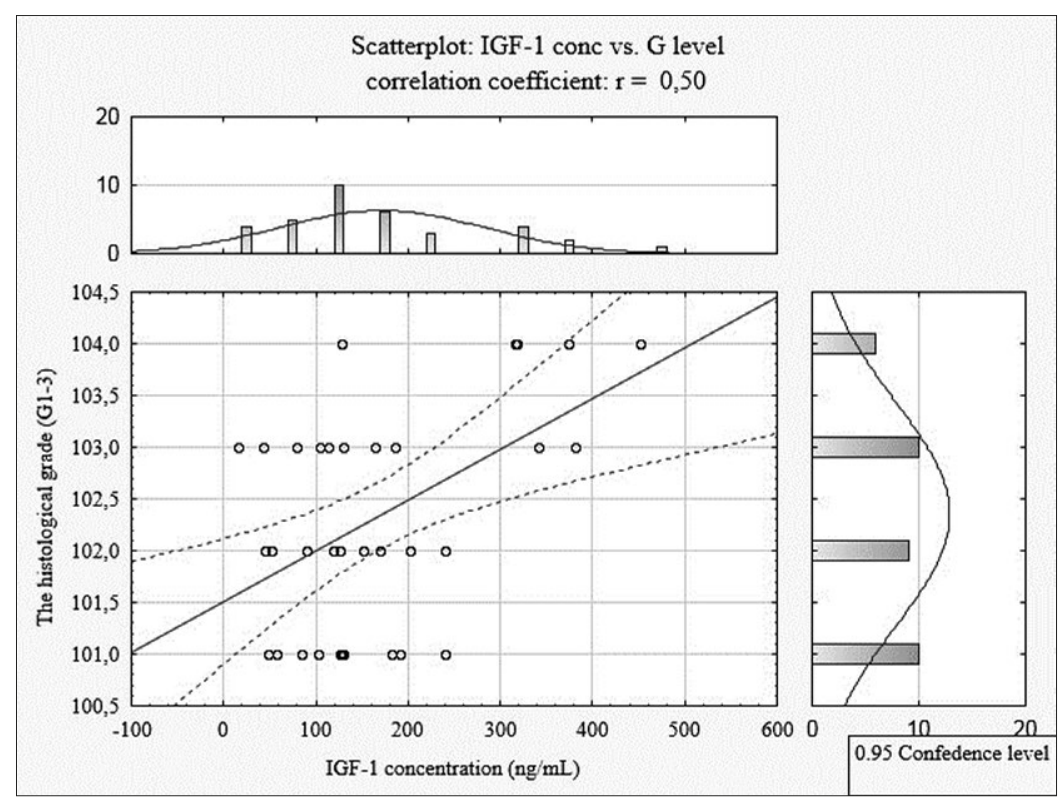

Fig. 1. Correlation between IGF-1 concentration and the histological grade (G1-3) of mammary tumours tion. Recently, Strage et al. (27) have reported higher mean concentrations of IGF-1 in serum of female dogs with mammary masses than in healthy ones. In human medicine many authors $(2,15)$ have also found significantly higher levels of serum IGF-1 in women with breast cancer compared to healthy controls. Moreover, numerous studies have demonstrated a relationship between increased circulating levels of IGF-1 and breast cancer risk in women (9). These findings indicate that circulating IGF-1 plays an important role in mammary gland tumorigenesis both in women and female dogs.

IGF-1 is one of the most potent mitogens for normal mammary epithelial cells and breast cancer cells (10, 30 ) and mediates in survival and transformation, key factors affecting tumour development $(1,10)$. There is evidence indicating that IGF-1 is a potent inhibitor of apoptosis, including that induced by cytotoxic chemotherapeutic agents (30), and regulates the expression of numerous genes implicated in breast tumorigenesis (1). Studies have demonstrated that IGF-1 stimulates angiogenesis via up-regulation of VEGF and COX-2 (20), and plays a role in cell-cell adhesion and cell migration, promoting invasion and metastasis $(24,28)$. In addition, there is interaction between steroid hormones (estrogen and progesterone) and the GH/IGF-1 axis in mammary gland development and breast cancer progression (10).

In canine mammary carcinoma, tissue IGF-1 has been positively correlated with tumour malignancy, as well as with tissue levels of progesterone and $17 \beta$-estradiol (18). The highest levels of IGF-1 have been observed in the most aggressive types of tumours. Significantly higher serum IGF-1 concentrations have been shown in the dogs with malignant tumours with recurrences and metastases compared to those with non-recurring and non-metastasizing tumours (19). These findings correspond with the results of our study. We observed the highest mean serum IGF-1 concentration in female dogs with histological grade 3 mammary carcinomas. This suggests that high circulating IGF-1 level in female dogs with mammary carcinoma may promote a more aggressive transformed phenotype of tumour cells with increased cell spreading.

Some studies in women with breast cancer (6) and in female dogs with mammary malignant tumours $(7,19)$ indicate the potential prognostic value of serum IGF-1 levels. Queiroga et al. (19) have found a relationship between high serum and intratumoral IGF-1 concentrations and a worse prognosis. This agrees with the immunohistochemical study by Jaiilardon et al. (7) which has shown that IGF-1 receptor (IGF-1R) overexpression is associated with shorter overall survival and shorter disease-free times in female dogs with mammary carcinoma. However, more studies are needed to confirm these findings.

The liver is the primary source of circulating IGF-1 but there are multiple tissues, including mammary gland, where IGF-1 synthesis does occur $(22,25)$. Moreover, IGF-1 may be produced by the neoplastic cells and acts on a tumour as an autocrine growth factor $(19,23)$. The higher concentrations of IGF-1 in the serum of female dogs with mammary tumours, observed in our and other studies, may indicate that development of neoplasm in the mammary gland stimulates local or/ and systemic IGF-1 secretion. It is postulated that some amounts of IGF-1 produced locally by the tumour cells might enter the circulation and lead to increasing the serum concentration (19).

The actions of IGF-1 are mediated primarily by the IGF-1R (28). According to the study by Jaillardon et al. (7) IGF-1R over expression is common in canine invasive mammary carcinoma and related to a poor clinical outcome, particularly in the triple negative subtype (defined by the lock of estrogen receptor (ER) and progesterone receptor (PR), and epidermal growth 
factor receptor type 2 (HER2) over expression). This opens the way for a search for new therapeutic methods, including anti-IGF-1R therapies in female dogs with malignant mammary tumours. Currently, in human medicine studies are being conducted on using anti-IGF-1R inhibitors for therapies of breast cancer (8).

Circulating IGF-1 is regulated by GH. It is known that both normal mammary glands of female dogs and mammary tumours produce $\mathrm{GH}$ (5). Circulating GH and IGF-1 concentrations increase in response to endogenous progesterone and synthetic progestins (13). There is also evidence to suggest that estradiol increases an expression of IGF-1 mRNA in normal mammary tissue (21). To exclude the impact of steroid hormones on serum IGF-1 concentrations in our study we have included only female dogs in anestrus.

In conclusion, the results of our study have demonstrated significantly higher concentrations of IGF-1 in the serum of female dogs with mammary tumours than in healthy controls and a positive correlation between serum IGF-1 and the histological grade of malignant tumours. These findings suggest that IGF-1 plays an important role in the pathogenesis of canine mammary tumours. Moreover, high circulating IGF-1 levels may reflect tumour cell differentiation into a more aggressive phenotype. Further studies are needed in order to better explain the importance of circulating levels of IGF-1 in disease risk and progression as well as to determine its prognostic value.

\section{References}

1. Christopoulos P. F., Msaouel P., Koutsilieris M.: The role of the insulin-like growth factor-1 system in breast cancer. Mol. Cancer 2015, 14, 43-56.

2. Coskun U., Günel N., Sancak B., Günel U., Onuk E., Bayram O., Yilmaz E., Candan $S$., Ozkan $S$.: Significance of serum vascular endothelial growth factor, insulin-like growth factor-I levels and nitric oxide activity in breast cancer patients. Breast 2003, 12, 104-110.

3.Dąbrowski R., Szczubiat M., Kostro K., Wawron W., Ceron J. J., Tvarijonaviciute A.: Serum insulin-like growth factor-1 and C-reactive protein concentrations before and after ovariohysterectomy in bitches with pyometra. Theriogenology 2015, 83, 474-477.

4. Elston C. W., Ellis I. O.: Assessment of histological grade, [in:] Elston C. W., Ellis I. O. (ed.): The breast. Churchill Livingstone, Edinburgh 1998, p. 356-384 .

5. Garderen E., van, de Wit M., Voorhout W. F., Rutteman G. R., Mol J. A., Nederbragt H., Misdorp $W .:$ Expression of growth hormone in canine mammary tissue and mammary tumors. Evidence for a potential autocrine/paracrine stimulatory loop. Am. J. Pathol. 1997, 150, 1037-1047.

6. Hartog H., Boezen H. M., de Jong M. M., Schaapveld M., Wesseling J., van der Graaf $W$. T.: Prognostic value of insulin-like growth factor 1 and insulin-like growth factor binding protein 3 blood levels in breast cancer. Breast 2013, $22,1155-1160$

7. Jaillardon L., Abadie J., Godard T., Campone M., Loussouarn D., Siliart B., Nguyen F.: The dog as a naturally-occurring model for insulin-like growth factor type 1 receptor overexpressing breast cancer: an observational cohort study. BMC Cancer 2015, 15, 664-676.

8. Jones R. L., Kim E. S., Nava-Parada P., Alam S., Johnson F. M., Stephens A. W., Simantov R., Poondru S., Gedrich R., Lippman S. M., Kaye S. B., Carden $C$. $P$.: Phase I study of intermittent oral dosing of the insulin-like growth factor- 1 and insulin receptors inhibitor OSI-906 in patients with advanced solid tumors. Clin. Cancer Res. 2015, 21, 693-700.

9. Kaaks R., Johnson T., Tikk K., Sookthai D., Tjonneland A., Roswall N., Overvad K., Clavel-Chapelon F., Boutron-Ruault M. C., Dossus L., Rinaroli S. Romieu J., Boeing H., Schütze M., Trichopoulou A., Lagiou P., Trichopoulos D., Palli D., Grioni S., Tumino R., Sacerdote C., Panico S., Buckland G., Argüelles M., Sanchez M. J., Amiano P., Chirlaque M. D., Ardanaz E., Bueno-
-de-Mesquita H. B., van Gils C. H., Peeters P. H., Andersson A., Sund M., Weiderpass E., Gram J. T., Lund E., Khaw K. T., Wareham N., Key T. J., Travis R. C., Merritt M. A., Gunter M. J., Riboli E., Lukanova A.: Insulin-like growth factor I and risk of breast cancer by age and hormone receptor status - A prospective study within the EP-IC cohort. Int. J. Cancer 2014, 134, 2683-2690.

10. Kleinberg D. L., Wood T. L., Furth P. A., Lee A. V.: Growth hormone and insulin-like growth factor-I in the transition from normal mammary development to preneoplastic mammary lesions. Endocr. Rev. 2009, 30, 51-74.

11. McGreevy P. D., Thomson P. C., Pride C., Fawcett A., Grassi T., Jones B.: Prevalence of obesity in dogs examined by Australian veterinary practices and the risk factors involved. Vet. Rec. 2005, 156, 695-702.

12. Misdorp W., Else R. W., Hellmen E., Lipscomb T. P.: Histological classification of mammary tumours of the dog and the cat, [in:] Schuman F. Y. (ed.): WHO international histological classification of tumors of domestic animals. Armed Forces Institute of Pathology, Washington 1999, p. 18-25.

13. Mol J. A., van Garderen E., Rutteman G. R., Rijnberk A.: New insights in the molecular mechanism of progestin-induced proliferation of mammary epithelium: induction of the local biosynthesis of growth hormone $(\mathrm{GH})$ in mammary gland of dogs, cats and humans. Mol. Biol. 1996, 57, 67-71.

14. Oosterlaken-Dijksterhuis M. A., Kwant M. M., Slob A., Hellmen E., Mol J. A.: IGF-1 and retinoic acid regulate the distribution pattern of IGFBPs synthesized by the canine mammary tumour cell line CMT-U335. Breast Cancer Res. Treat. 1999, 54, 11-23.

15. Pasanisi P., Bruno E., Venturelli E., Manoukin S., Barile M., Peissel B., De Giacomi C., Bonanni B., Berrino J., Berrino F.: Serum levels of IGF-I and BRCA penetrance: a case control study in breast cancer families. Fam. Cancer 2011, 10, 521-528.

16. Pinho S. S., Carvalho S., Cabral J., Reis C. A., Gärtner F.: Canine tumours: a spontaneous animal model of human carcinogenesis. Transl. Res. 2012, 159, 165-172.

17. Pollak M.: The insulin and insulin-like growth factor receptor family in neoplasia: an update. Nat. Rev. Cancer 2012, 12, 159-169.

18. Queiroga F. L., Perez-Alonza M. D., Silvan G., Pena L., Lopes C. S., Illera J. C.: Crosstalk between GH/IGF-1 axis and steroid hormones (progesterone, 17-beta-estradiol) in canine mammary tumours. J. Steroid Biochem. Mol Biol. 2008, 110, 76-82.

19. Queiroga F. L., Perez-Alonza M. D., Silvan G., Pena L., Lopes C. S., Illera J. C. Serum and intratumoural GH and IGF-I concentrations: Prognostic factors in the outcome of canine mammary cancer. Res. Vet. Sci. 2010, 89, 396-403.

20. Reinmuth N., Liu W., Fan F., Jung Y. D., Ahmad S. A., Stoeltzing O., Bucana C. D., Radinsky R., Ellis L. M.: Blockade of insulin-like growth factor I receptor function inhibits growth and angiogenesis of colon cancer. Clin. Cancer Res. 2002, 8, 3259-3269.

21. Ruan W., Catanese V., Wieczorek R., Feldman M., Kleinberg D. L.: Estradiol enhances the stimulatory effect of insulin-like growth factor-I (IGF-I) on mammary development and growth hormone-induced IGF-I messenger ribonucleic acid. Endocrinology 1995, 136, 1296-1302.

22. Ruan W., Kleinberg D. L.: Insulin-like growth factor I is essential for terminal and bud formation and ductal morphogenesis during mammary development. Endocrinology 1999, 40, 5075-5081.

23. Sachdev D., Yee D.: The IGF system and breast cancer. Endocr. Relat. Cancer 2001, 8, 197-209.

24. Samani A. A., Yakar S., Le Roith D., Bradt P.: The role of the IGF system in cancer growth and metastasis: overview and recent insights. Endocr. Rev. 2007, 28, 20-47.

25. Sherlock M., Toogood A. A.: Aging and the growth hormone/insulin like growth factor-I axis. Pituitary 2007, 10, 189-203.

26. Sleeckx N., de Rooster H., Veldhuis Kroeze E. J., van Ginneken C., van Brantegem L.: Canine mammary tumours, an overview. Reprod. Domest. Anim. 2011, 46, 1112-1131.

27. Strage E. M., Lewitt M. S., Hanson J. M., Olsson U., Norrvik F., Lilliehöök I., Holst B. S., Fall T.: Relationship among insulin resistance, growth hormone, and insulin-like growth factor I concentrations in diestrus Swedish elkhounds. J. Vet. Intern. Med. 2014, 28, 419-428.

28. Surmacz E.: Function of the IGF-I receptor in breast cancer. J. Mammary Gland Biol. Neoplasia 2000, 5, 95-105.

29. Tvarijonaviciute A., Tecles F., Carillo J. M., Rubio M., Ceron J. J.: Serum insulin-like growth factor-1 measurements in dogs: Performance characteristics of an automated assay and study of some sources of variation. Can. J. Vet. Res. 2011, 75, 312-316.

30. Werner H., Le Roith D.: The insulin-like growth factor-1 receptor signaling pathways are important for tumorigenesis and inhibition of apoptosis. Crit. Rev. Oncog. 1997, 8, 71-92.

Corresponding author: Marek Szczubial, DVM, PhD Hab., Głęboka 30 20-612 Lublin, Poland; e-mail: marek.szczubial@up.lublin.pl 